\title{
(Post)utopian Vineland: Ideological Conflicts in the 1960s and the 1980s
}

Lovorka Gruic Grmusa

\section{(2) OpenEdition \\ Journals}

Electronic version

URL: https://journals.openedition.org/ejas/8833

DOI: $10.4000 /$ ejas.8833

ISSN: 1991-9336

Publisher

European Association for American Studies

\section{Electronic reference}

Lovorka Gruic Grmusa, "(Post)utopian Vineland: Ideological Conflicts in the 1960s and the 1980s", European journal of American studies [Online], 5-3 | 2010, document 4, Online since 07 December 2010, connection on 08 July 2021. URL: http://journals.openedition.org/ejas/8833 ; DOI: https://doi.org/ 10.4000/ejas.8833

This text was automatically generated on 8 July 2021.

Creative Commons License 


\title{
(Post)utopian Vineland: Ideological Conflicts in the 1960s and the 1980s
}

\author{
Lovorka Gruic Grmusa
}

1 Any attempt at comprehending a particular text from a historical perspective must look far beyond the specifically esthetic parameters of a text and consider social, political, historical and economic factors that condition both the writer and his work. The point of departure for this textual analysis is the study of poetics that involves transgression between society, writer, text, and critic. This reading strategy envisions the text as an integral part of the historical context in which it first appeared and as it interacts today with a multiplicity of readers.

2 Thomas Pynchon, arguably America's most important living novelist, started publishing his work during the period of the Vietnam War. Under the influence of the antiwar movement and the counterculture, and the dramatic social struggle and ideological conflicts in the 1960s, early 1970s, and more conservative 1980s, he attacks the military, the state, and other forces of domination. A very fashionable topic of socio-historical and cultural research, the American sixties were widely interpreted in the late eighties and early nineties, revealing a backlash against Reagan's and Bush's conservative presidencies.

3 Pynchon's Vineland is the novel that mirrors the sixties and eighties in the U.S. and is therefore particularly suitable for the analyses of historical phenomena, with various social and political issues, ideological clashes, anti-war struggles, and the rise of counterculture, when drugs functioned as a literal opiate of the masses. Although it focuses on the sixties, it brings controversial aspects of U.S. history and culture into view, beginning with the execution of Joe Hill in 1915, to the labor conflicts in the 1930s, the blacklist period in the 1950s, the hippie movement in the sixties, to the Reaganomic politics of the eighties, "pictured as a chronicle of violent class struggle and ruthless governmental repression" (Dickson 140). Thus, this article offers a comprehensive perspective on ideological conflicts in the sixties and eighties, as presented in Thomas Pynchon's novel Vineland. It locates and follows the various trajectories of events and developments that the book invites the reader to pursue, 
presenting them against the background of important political events that eventually led to the escalation of right-wing violence, paranoia and even nostalgia for the 1960 s.

Vineland very title draws attention to its historical background. "Vinland" was the name used by Vikings for the American soil which they came upon about four hundred years before Columbus discovered it, the land which was afterwards named after another explorer, Amerigo Vespucci (Dickson 139). These triple "discoveries" of America indicate various beginnings of a nation, pointing out that in time a land can be discovered over and over again, and multiplying its beginnings. The novel's title also implies the place of wine and abundance, an American dream of innocence and of Western utopian endeavor. The novel depicts both historical and individual attempts to construct alternative ideologies through art, love, and the labor movement, seeking to replace Christianity and mechanistic science. The narrative reveals the inherent instabilities of these transcendent new ideologies, rendering their collapse, and proving that utopia in postmodern society is already/also post-utopia.

The novel demonstrates how the hippie movement had a lot of potential but was destroyed from within, as is so often the case - people destroy their own causes. Or as Samuel Chase Coale notes: they are "destroyed by government agents, government snitches, and co-opted flower children who betray their own kind" (164). It also depicts the eighties as a much calmer, seemingly less active period that concentrated on family values and bonding, which turned out an excellent protection against political authoritarianism and made people more resistant to cooptation. The eighties gave the impression of being more effective (in the long run) than the sixties, which sort of "burnt out" quickly. As in his masterpiece Gravity's Rainbow, the author here illustrates how historiography has been co-opted by power interests to make unethical behavior acceptable, and how all-powerful processes of history intimidate people into accepting them as inevitable phenomena, presenting "repression as normal," so that vast power structures control their lives "confronted with the brutal fact that the State no longer needs to disguise its hostility" (Madsen 126; 128). Pynchon demystifies the origins of authoritarianism, demonstrating that modern technocracy and its subsidiaries are just constructs which can be dismantled the same way they were built (like weapons of mass destruction).

Pynchon does not pack Vineland with innumerable references to history, nor does he impregnate the text with philosophy, science, social theory or art, as he does in the minutest detail in Gravity's Rainbow. Mostly relying on the atmosphere of the sixties and eighties, eroding the boundary between fact and fiction, the text and its readers, and using abbreviated and diminished, flattened language (words such as: "rilly" or "s'matta?"), the author denies the readers the expected comfort of aesthetic distance that enables them to control the text. It brings them within Vineland. In the place of sophisticated conceit are countless references to the quotidian. The contemporary world of television, cars, computers, and music abounds in the novel, often with the names and dates of the shows, people, songs, and places that are commonplace in this world, such as the Eagles song "Take it to the Limit" or the 1983-84 NBA playoffs.

7 Unlike Gravity's Rainbow, where the 1960s appear only as prolepsis and displacement, in Vineland they appear analeptically, as a series of reminiscences. The emphasis on discontinuity, entropy, and virtuality clearly indicates an exploration of discrepancies, turbulences and ideological battles of postwar social life. But Vineland is not from the 1960s but about them: 
It thematizes the mediated nature of the 1960 s by filtering it through stories and anecdotes told by its middle-aged 'veterans' to teenage interlocutors, and indeed it (literally) appropriates their narrative reconstructions, takes over their nostalgic voices, and becomes another veteran of the time. (Mattessich 221)

The major historical and (post)utopian moments in Vineland occur in the sixties, but are examined through the contemporary frame of the eighties. The geographical location is the U.S.A., which is central to the historical, cultural and technological effects of the story. More precisely, the story takes place mostly in California. As Judith Chambers acknowledges: "It is not surprising that Pynchon chooses California, the state where strange is the norm ... the new America" (Chambers 190). Pynchon depicts northern California as magical: "crossing the Golden Gate Bridge represents a transition, in the metaphysics of the region" (314), "Vineland the Good" (322), "beautiful country" with "mass migration of freaks ... from L.A. north is spilling over into Vineland" (305). While further south, "as the fog now began to lift to reveal not the borderlands of the eternal after all, but only quotidian California again" (94), the author delineates "movies at malls letting out, bright gas-station oases in pure fluorescent spill, canopied beneath the palm trees, soon wrapped, down the corridors of the surface streets, in nocturnal smog, the adobe air, the smell of distant fireworks, the spilled, the broken world" (267). California is postmodern America.

9 The mythical Vineland is depicted as a place where utopian and post-utopian clash, where just like the Vikings might have felt viewing America's shore, early Spanish and Russian emigrants (Sasha's Old Leftist Families) had a sense

of some invisible boundary, met when approaching from the sea, past the capes of somber evergreen, the stands of redwood with their perfect trunks and cloudy foliage, too high, too red to be literal trees-carrying therefore another intention, which the Indians might have known about but did not share. (317)

10 This land appears as a safe harbor, a sanctuary through the centuries for those who have traveled a long way, and also as a hiding place of "another intention," a retreat from society (in contemporary society-from consumerism): secretive "territories of the spirit" (317). With their arrival, each new "species," "tribe," or generation pushes aside the old, crossing the "invisible boundary," and implementing their own ideologies, which gives this space utopian and post-utopian characteristics at the same time. The primeval utopia that "woge, creatures like humans but smaller" (186) inhabited was 'invaded' when the Indians came, so that

before the influx, the woge withdrew. Some went away physically, forever, eastward, over the mountains, or nestled all together in giant redwood boats, singing unison chants of dispossession and exile ... Other woge who found it impossible to leave withdrew instead into the features of the landscape, remaining conscious, remembering better times. (186)

11 Yurok and Tolowa Indians were "exiled" when Spanish and Russian settlers arrived, and "virtually erased from memory" (Harris 204). Each generation wrote a new and changed history of the old. Hippies thought that woge went "beneath the ocean" to see "how humans did with the world," and if humans did something "bad ... would come back, teach us how to live the right way, save us" (187).

Apart from these mythical accounts of the novel-the safe heavenly harbor that Vinland presented for the Scandinavians after crossing the Atlantic, and for each new group that arrived-it is important to evaluate the historical circumstances which serve as a background this fictive world is cradled in. 
13 In Vineland, the initial uprising of the hippy movement at the College of the Surf in California mirrors the reality of this time of change and pervasive belief in the power of action, when, it was held, governments could provide the conditions for economic growth and protect the vulnerable. Groups and individuals, it was believed, could act to fulfill their own dreams and to pursue their talents. The spirit of activism helped to distance the era of the 1960s from the apparent placidity of the Eisenhower era.

For many, Dwight David Eisenhower, elected to the White House in 1952 and re-elected in 1956, had become the personification of a benign father figure who, it seemed, had persisted but not led. His management was sometimes criticized although the economy (with occasional slowdowns) was good. By the turn of the decade, a thirst for action was beginning to manifest itself. The sixties were inventive, turbulent, spirited, and identified with action and motion. People wanted some sense of control over their destinies, just like Frenesi, one of the main characters in Vineland, felt she had had before Prairie was born. Here again an old American trait was asserting itself; people were seeking empowerment and the desire to be masters of their own fate.

President John F. Kennedy, elected in 1960, was youthful and projected an image of vigor, but his administration has sometimes been accused of raising expectations that could not be fulfilled. The liberal Democrats that peopled the administration for the greater part of the 1960s had no wish to generate a pervasive bureaucracy, but believed that government could make a difference. The average age of his cabinet (forty-seven) was ten years younger than that of Eisenhower. What attracted many Americans to Kennedy was his identification with service rather than business, his non-ideological commitment to the public domain, and his charm that dispelled any notion that his interests were purely self-serving.

The prosperity of the 1960s made possible the "War on Poverty," the mission to the moon and the arms race, the expansion of higher education, and the war in Vietnam, as it also perversely encouraged the outbreak of rioting by the poor in the cities. Universities rather than factories were at the cutting edge of this new frontier. The proportion of industrial workers was declining, while the number of white-collar workers was rising fast, and the suburbs were growing in influence.

17 After Kennedy's assassination, Lyndon Johnson committed himself to deliver the promises his predecessor outlined. He believed in victory over poverty and racism at home and in defeating communism abroad. But by the middle of the decade his optimism was straining credibility. Ghetto riots and the Vietnam quagmire were to prove fatal to the politics of hope. The war was devouring resources, and its escalation during 1965 strained Johnson's relationships with many reform allies. An anti-war sentiment was mounting. The optimism of the early 1960s was replaced by darker emotions, starting with the assassination of Kennedy in 1963, then the murder in 1965 of Malcolm X (the African American radical), followed by the assassinations of Martin Luther King and Robert Kennedy in 1968. As black violence flared, women, Native Americans, homosexuals, students, and others marched to demand their rights. Vietnam in particular became the focus of massive dissent. The demonstrations of various sorts escalated in the second half of the 1960s. Turbulences continued until the end of the decade with the crime rate rising.

With these historical facts in mind it is easier or more appropriate to interpret the sixties that Pynchon's protagonists inhabited-"preterite" characters dealing with their own desires for order and their complicities in power, human weaknesses, and 
ideologies. David Dickson notes that: "The heritage of Frenesi's family is portrayed as a continuity of engagement in American class struggles throughout the twentieth century" (164-165). The stories of Frenesi's parents, Sasha and Hubbell Gates, both activists in the McCarthy years, offer some of the history of that era. As Frenesi acknowledges:

her parents liked to proceed backward, into events of the past, in particular the fifties, the anticommunist terror in Hollywood then, the conspiracy of silence up to the present day. Friends of Hub's had sold out friends of Sasha's, and vice versa, and both personally had suffered at the hands of the same son of a bitch more than once. (81)

19 Pynchon is here referring to the late 1940s and early 1950s when Senator Joseph McCarthy began his witch hunt, producing blacklists and claiming to have the names of 205 Communist Party members who held high positions in the State Department. The leading anticommunist figure, McCarthy, inflicted fear among civilians. Pynchon uses fictive characters to depict those times.

20 In order to encompass a period span from the fifties to eighties with insight into the historical background and ideological striving of each decade, the novel is best examined with a certain chronology. Although Vineland is postmodern and highly nonlinear, this analysis demands re-ordering events in a certain sequence which will, for this purpose, be following characters through their revolutionary decades.

21 Raised in the family of authentic radicals, the daughter of Eula Becker and Jess Traverse, Sasha is a courageous woman who recognizes and fights the power conglomerates that have claimed her husband and daughter. She criticizes the patriarchal system that induces repression and explains that the real world consequences of this system occur too often without correction:

The injustices she had seen in the streets and fields, so many, too many times gone unanswered-she began to see them more directly, not as world history of anything too theoretical, but as humans, usually male, living here on the planet, often well within reach, committing these crimes, major and petty, one by one against other living humans. Maybe we all had to submit to History, she figured, maybe not-but refusing to take shit from some named and specified source-well, it might be a different story. (80)

While her thoughts articulate the necessary caution that must be prescribed against the "named and specified source" of oppression, she is aware that no one is free of contagion, specifically if looking at her own family. Identifying a "source" of injustice will not be as easy as it may once have been. In the celluloid, post-WWII world to which Sasha refers, the forces of evil are so subtle, seductive, and widespread that they are harder to isolate and name. Still, as Peter Brigg notes: "Vineland's central subject is the ongoing persecution by Right Wing America (the FBI, the Presidencies and their links with the Mafia, the zaibatsus, and corporate America) of dopers, musicians, and radicals" (96), which explains ideological clashes.

Sasha plays the role of a blacklist Hollywood script reader during the McCarthyist 1950s, and she "has a history of union activism in Hollywood, in the unions that Ronald Reagan, as president of the Screen Actors' Guild, helped to suppress" (Madsen 131). Therefore, she "understands the simulacral modality of order in a postwar dispensation" (Mattessich 223), and how laden with contradiction it is:

To Sasha the blacklist period, with its complex court dances of fuckers and fuckees, thick with betrayal, destructiveness, cowardice, and lying, seemed only a 
continuation of the picture business as it had always been carried on, only now in political form. Everyone they knew had made up a different story, to make each of them come out looking better and others worse. "History in this town," Sasha muttered, "is no more worthy of respect than the average movie script, and it comes about in the same way-as soon as there's one version of a story, suddenly it's anybody's pigeon ... By now the Hollywood fifties is this way-over-length, multitude-of-hands rewrite-except there is no sound, of course, nobody talks. It's a silent movie." (81) history in her "real" life. She is the sixties revolutionary turned snitch, that crystallizes as a victim, both genetically and socially, perfectly encoded to collaborate with the oppressor. But Pynchon does not absolve her of responsibility. She views the world through the screen and the camera, either watching movies, or shooting documentaries during confrontations in the sixties. Distanced from the real (which is why she is not afraid of getting hurt during the assault on the College of the Surf), she is removed to celluloid detachment:

as if on some unfamiliar drug, she was walking around next to herself, haunting herself, attending a movie of it all. If the step was irreversible, then she ought to be all right now, safe in a world-next-to-the-world that not many would know how to get to, where she could kick back and watch the unfolding drama. (237)

Achieving distance, she is "safe," her deeds apparently inconsequential. At one point she perceives Weed, her lover, just as "a character in the movie ... but even sex was mediated for her now-she did not enter in" (237).

As a student at Berkeley, Frenesi's inability to overcome a desire for "make-believe" instigates her political activities, as well as her betrayal of fellow activists at the College of the Surf. She evokes for the novel a more general dynamic of counterculture: evasion and refusal of "history." Frenesi's "make believe-her dangerous vice-that she was on 
her own, with no legal history, no politics, only an average California chick, invisible" (236), demonstrates that politics is for her also an escape from politics. Her escape with Brock Vond (who manipulates her into causing the death of Weed Atman) in turn delivers her to the political structures of social control (Vond, knowing her complicity in the murder, uses the information to keep her working for the FBI). Here Pynchon narrates Frenesi's confusion, with the "evil" forces slowly subsuming her in the FBI plots and alienating her from her friend DL (Darryl Louise Chastain) and her mother.

Frenesi's slow metamorphosis from activist to snitch, catalyzed by a sexual attraction for Brock Vond, becomes more and more impossible for her to repress. She is a passive medium through which Brock destroys the hippy movement and damages Weed. He soon influences even her filming, "he was not only seeing the outtakes, but also making suggestions about what to shoot to begin with" (209). This is made explicit in the scene right after they "made love," with Brock saying: "You're the medium Weed and I use to communicate, that's all, this set of holes, pleasantly framed, this little femme scampering back and forth with scented messages tucked in her little secret places" (214). Even when she is out of his reach, Brock gets to her "mentally," intruding upon her mind. For example, after Prairie was born, she conjures him up as if invoking a deity: "With his own private horrors further unfolded into an ideology of the mortal and uncontinued self, Brock came to visit, and strangely to comfort, in the half-lit hallways of the night" (286-87).

Zoyd, Frenesi's first husband and Prairie's father, lives on an income of social security for feigning insanity. His world is that of drug fantasies and obsession with Frenesi, which does not make him very responsible:

a hippie, pot-smoking, small time rock and roll playing, long haired freak of the $60 \mathrm{~s}$ ... Zoyd is part of a government funded program designed to keep the memory of the 60 s alive as a memory of insanity, and the opening scene of the novel is a comic conflation of representations of the 60s in the age of Reagan: A hippie wearing a dress, wielding a chain saw, performing a self-and property-destroying act which is broadcast live on television. (Berger 3)

31 His unrestrained fancy is visible through his views of the world: "the Mellow Sixties, a slower-moving time" when, he assured himself: "the visible world was a sunlit sheep farm. War in Vietnam, murder as an instrument of American politics, black neighborhoods torched to ashes and death, all must have been off on some other planet" (38). He refuses to come to terms with reality until he is emotionally forced to grapple with fatherhood. During an illness, Prairie, age four, looks at Zoyd with "dull, hot eyes, snot crusted on her face, hair in a snarl, and croaked," and she asks: "Dad? Am I ever gonna get bett-or?" (321) Just then Zoyd "had his belated moment of welcome to the planet Earth" (321). It marks the end of his "abstract" existence. He is initiated to the material world. All becomes inept when faced with the flesh and blood reality of his daughter: "no time for these hardened criminal drug dealers I used to hang out with, I'm totally reformed" (303).

Frenesi and Zoyd are perfect examples of how the hippy generation lived and thought: experimenting sexually, cherishing an interest in eastern mysticism, spreading love, using marijuana and psychedelic drugs, which makes Vineland: "a lysergic-acid [LSD] Icelandic saga" (Leonard 67), and thinking utopian thoughts of how they were completely "liberated." As Pynchon nicely positions Frenesi's thoughts: "She had been privileged to live outside of Time, to enter and leave at will, looting and manipulating, weightless, invisible" (287). Just like Frenesi and Zoyd, the counter-culture cultivated 
specific attitudes of conduct and artistic expressions (such as long hair, rock music, drug use) that gradually spread through America and the world: millions of young people "seeking a nonmaterialistic, peace-loving society in which they could be their natural and individual selves" (Rielly 87). In 1967 thousands of young people poured into the Haight-Ashbury district of San Francisco during the "Summer of Love." The area was soon known as "Hashbury," populated by mostly younger Americans. Attending rock concerts and other happenings of their interest, the "flower children" tried to create alternative lifestyles that were experimental and communal. The hippies thought they were the instigators of the new revolution (which in a way they were), assaulting conventional bourgeois values and rejecting the older generation's form of behavior and puritan codes. Many respectable Americans thought of them as abusers of American culture and the American political order.

It is not surprising that after experimenting with communal living, free love, and alternate types of spirituality, Frenesi perceives her newborn child as: "Looking to control her ... robbing her of milk and sleep, acknowledging her only as a host" (286). Prairie was "painfully" real (as Zoyd realized too). She was not one of the films Frenesi was watching or making, the baby was there and needed nourishment. Feeling as if "[n]ow Time had claimed her again, put her under house arrest, taken her passport away. Only an animal with a full set of pain receptors after all" (287); Frenesi escapes again.

Her shattered psyche and confusion surface once more when she rejoices during "the Nixon Repression," declaring: "finally-here's my Woodstock, my golden age of rock and roll, my acid adventures, my Revolution," when she was free "to act outside warrants and charters, to ignore history and the dead, to imagine no future, no yet-tobe-born, to be able simply to go on defining moments only, purely, by the action that filled them" (71-72). She is simply nauseated with any responsibility, including the hippy movement that demands dedication. Frenesi is "at home" populating "no longer the time the world observed but game time, underground time, time that could take her nowhere outside its own tight and falsely deathless perimeter" (293).

DL, Frenesi's best friend, is the character Pynchon sets as a foil against the idealistic Frenesi. She is a "lived solid woman ... tall and fair ... athletic, even warriorlike" (99), aware that "her body belonged to herself" (128). DL is a sharp contrast to Frenesi's lack of self-control and her dreams "of a mysterious people's oneness" (117). She grapples with her failings more realistically than Frenesi and Zoyd do, and deals with problems as if they were material and therefore solves them, while Zoyd mostly fantasizes and Frenesi is too irresponsible, surrendering "to a life scripted by government institutions" (Ostrander 131).

Vineland also marks counterculture's escape from technocratic society. Popular with hippies and other members of the counterculture during the 1960s were so called "soft drugs." The proliferation of marijuana among students increased. Pynchon describes:

Like loaves and fishes, the hand-rolled cigarettes soon began to multiply, curls of smoke to become visible, all from the same bag of what drug-agency reports were to call 'extremely potent' Vietnamese buds, perhaps, it was later suggested, brought in by somebody's brother in the service, since it sure wasn't surfer product. (206)

37 Alluding to Jesus Christ and how he fed his followers, the author presents the hippy movement as a pseudo-religious ideology. 

government: "it was still unthinkable that any North American agency would kill its own civilians and then lie about it" (248). Whether it is "the infamous federal-state Campaign Against Marijuana Production," or the "Political Re-Education Program, or PREP" (268), the Drug Enforcement Agency branch of the justice department - "invaders and oppressors" (49)-is being held responsible and behind it all; which is understandable since the novel deals mostly with the hippy generation. As Deborah Madsen notes: "Postmodern America is a world dominated by the enemy within. Federal agencies, which ostensibly protect, issue instead a sinister threat to those who question the power of the State" (Madsen 128).

radicals in the late sixties and of drug addicts in the eighties. Brock saw

all around him in those days ... people his age surrendering to dangerous gusts of amusement, even deciding never to return to regular jobs and lives. Colleagues grew their hair long and ran off with adolescents of the same sex to work on psychedelic-mushroom ranches of faraway coasts. (278-79)

Indeed, students, artists, radical intellectuals and others dropped out of mainstream society and joined the hippy movement. This was a time of "a utopian moment in which America's rebellious sons and daughters strove for authenticity and sought to perfect the world with moral and political ideals that envisioned an almost apocalyptic change" (Moser 39). 

sixties radicals, concluding they were "children longing for discipline," "the sort of mild herd creatures who belonged, who'd feel, let's face it, much more comfortable, behind fences" (269). He hopes he could reform them so they can take their restorative function within society, just like "the people themselves" did, he thought, with "Nixon's election in '68" (273). Brock exerts a sadistic control over most characters in the novel, running a military operation designed to rid the nation of drugs and determined to destroy each season's marijuana crop, controlling Frenesi and intervening with the life of Zoyd and Prairie. There are stronger forces behind him, and repeated references to the Nixon and Reagan presidencies who manipulate the agency, but he does stand as the main tool of oppression in Vineland. Still, we have to look behind the scenes of the novel and into the history because that was the reality in which Pynchon lived and wrote.

The main political figure in the late sixties until the mid-seventies was Richard Nixon, who had a long political career in Washington, starting in 1952 as Eisenhower's vice president and serving two terms. In 1960 he lost as the Republican presidential candidate (Kennedy won), and finally in 1968 was elected the President of the United States and reelected in 1972. In the wake of the Watergate scandal, in 1974, Nixon resigned. Various historical analyses say that his victory in 1968 owed more to disenchantment with the Johnson administration than it did to his own personal appeal. Nixon's decision to pin his hopes on the "silent white," the law-abiding taxpayers who had not been shouting, rioting and demonstrating, turned out to be productive. He was not only against the Johnson administration but positioned himself against the various protest movements of the New Left, appealing to the "forgotten, orderly Americans." His credo was that white workers need not have been racist to wonder just what the society was offering them, and to question why their tax dollars should go to ghetto rioters and disorderly students. His victory, it has been said, "was a victory for 'the unyoung, the unblack, and the unpoor"' (Heale 101). He encouraged conservative impulses, turning his back on the sixties. When massive anti-war demonstrations were organized, due to the extension of the war into Cambodia, federal troops were called in and some demonstrators were killed. His campaigns against black radicals and rebellious students touched the sentiments of the "silent majority" (recalling "loud minority" and the "good folks" from Gravity's Rainbow (755), the outstanding, hardworking citizens versus the harmonica players). The political and cultural conservatism of the Nixon administration was to ease the way for the rise of the New Right, which peaked when Reagan was elected. The Watergate issue unraveled fatally from 1972 to 1974, bringing down the Nixon presidency.

Most of the historians agree that with Ronald Reagan's election in 1980, "the United States took a major shift rightwards for the first time since 1920s" (Gosse 8). Even during Nixon's presidency, which paved the way for the ascendance of conservative Republicans, liberal government steadily expanded because of continuous pressure from grassroots social movements and the inclinations of those in power raised on the premises of the New Deal. Reagan, a charismatic orator, promised to restore America as a dominant world power, promoted moral order based explicitly on the heterosexual, patriarchal family, and swore to limit the federal government's role as a re-distributor of wealth and regulator of business. Indeed, he did lower taxes and regulations upon the wealthiest in America, so that the rich got richer, but "the working classes and poor

European journal of American studies, 5-3 | 2010 
got a lot poorer" (Gosse 13). Reagan allegedly once said a hippie was someone who "dresses like Tarzan, has hair like Jane, and smells like Cheetah" (Cannon 148). This is how it is depicted in Vineland: "it's the whole Reagan program, isn't it-dismantle the New Deal, reverse the effects of World War II, restore fascism at home and around the world" (265). David Thoreen acknowledges: "Pynchon's focus on the threat to those freedoms that escalated during the Reagan presidency is a natural extension of his interest in (and dramatization of) imperialism ( $V$.$) and the concentration of power$ (Gravity's Rainbow)" (218). No wonder the old hippies were dissatisfied, having lost their dreams but not gaining anything in return, getting both poorer and being forgotten: "a romantic lost tribe with a failed cause, likely to remain unfound in earthly form but perhaps available the way Jesus was to those who 'found' him" (207-208).

Unlike her parents, who were unable to cope with reality and the change in the eighties, Prairie turned out quite good, considering that her mother abandoned her when she was still a baby, and as the narrator states, she lived with "a dope fiend father" (57), "vile-minded" (60), absorbed in his sexual fantasies in front of the TV. Although inheriting some traits from her parents, for example, a fascination with the transcendent, Prairie is also rooted in the real. When watching the replay of the assault of government troops on the College of the Surf, Prairie shouts: "She could get herself killed," (248) because her mother held the camera, shooting the film, and never pulling back. Unlike Frenesi, who cannot sustain the illusion of hovering above reality, Prairie is realistic, aware of the danger Frenesi was in during the assault.

The fleeting reality, the history that Prairie tries to make sense of, is "located" within the multilayered spheres of the old and the new, from labor conflicts in the thirties to Reagan's politics of the eighties. In an overlap of history, media, oral narration and technology, Prairie learns of the inexperienced, the forever gone space-time of the sixties in America. Her quest for her mother is revealed largely through photographs, computer data, historical documents, DL's narration and especially through cinematography. To recapture the mother she never knew and the lost world of the sixties that was her mother's milieu, she must rely on various media: first, that of a computer (on which she reviews her mother's file, including photographs), and second, film, though belonging as she does to a TV-oriented generation, she would have preferred a videotape. Her quest succeeds and her knowledge expands. The effects of history on her family, once illuminated, become somehow united with the public history-therefore more meaningful-blending the pastoral myth of union with history. As the 1960s background is replaced by a 1980s setting, the hippy ideology is largely displaced by a cult of technology, its most blatant manifestation being obsessive television viewing. The power of TV is demonstrated as deadening people who have given up action and movement and who remain passive, staying at home, substituting television for experience. The most extreme example of its twenty-four hour public is the Thanatoid community of "living dead," who spend most of their time in front of the "Tube." Their world is described "colder than you ever want to find out about" (31), their population "growing steeply" ever "since the end of the war in Vietnam" (320).

But the eighties are also presented as the time of family values and in tune with the politics, which is symbolically depicted at the reunion in Vineland. Even Frenesi, who has not been there since high school, is manipulated into coming by Brock Vond, and she takes her second husband and son along. Everyone gathers at the annual BeckerTraverse family reunion. Brock arrives at night by helicopter, a military-style raid, to 
kidnap Prairie, who would give him renewed control over all the others. Prairie rejects him, breaking the magic spell he has had over her mother. Then he is pulled up: Suddenly, some white male far away must have wakened from a dream, and just like that, the clambake was over. The message had just been relayed by radio ... Reagan had officially ended the "exercise" known as Rex 84 ... Brock, his authorizations withdrawn, now being winched back up, protesting all the way. (376)

51 The plot, in a way, follows real space-time reality with its allusions to authentic historical events. Here Pynchon draws attention to a military exercise known as the Readiness Exercise 1984, or Rex 84.

In April 1984, President Reagan signed Presidential Directive 54, authorizing the Federal Emergency Management Agency to conduct a simulation of a "state of domestic national emergency" as a result of a U.S. military operation in Central America (Helms 60). The first reports about Rex 84 appeared in the Miami Herald on July 5, 1987. According to the Herald, the plan the Rex 84 group produced called for the detention of up to 400,000 undocumented immigrants in internment centers at military bases around the country. These would eventually become known as the "Rex 84 camps." If necessary, U.S. military forces, including the National Guard, would be deployed for domestic law enforcement, and state and local military commanders could assume control of state and local governments if so directed by the president. Rex 84 also included plans for suspension of the Bill of Rights of the U.S. Constitution (which was probably the worst part) for the duration of the national emergency (Thoreen 219). Jeff Baker underlines Vineland's

portrayal of a Reagan-era fascism not only accepted but embraced by an overwhelming majority of Americans, the lamentable failure of America to live up to its promise as a new beginning that might have been untainted by the "death structures" of trade and politics. (176)

In Vineland, Brock dies by accident, rushing back in a stolen helicopter. The "oppressed" are free from the "oppressors" for a while. His death opens up a new territory for the dope-smoking, irreverent, creative, humble, and hope-filled preterite. As Pynchon ironically states, the hippy movement with its pseudo-religious ideology was long gone, yet the dream remained, together with "a romantic lost tribe with a failed cause" (207). Though the eighties were much different than the sixties, the people had un unbroken community and a vigorous vitality which made their alliances maybe even stronger than in the sixties, and it seems there were less snitches with communism fading away.

The faith in divine justice lies at the heart of the union of Eula and Jess, and the annual return to celebrate their community, reuniting the "tribe" just like the "Yurok and Tolowa people," who inhabited these "territories of the spirit" (317) before them, and "woge" (186), the not quite human, before the first humans arrived. Taking place every year, the Becker-Traverse reunion gives hope: Thanatoids awake and make eye-contact, Prairie meets her mother, and the communards are bonding, playing cards, and discussing politics. In the mythical town of Vineland, Prairie's quest is finally over. Her mother is finally forced into the world of the physical and the imperfect: "a woman about forty, who had been a girl in a movie, and behind its cameras and lights, heavier than Prairie expected, sun damage in her face here and there, hair much shorter" (367).

During the reunion various stories are heard: 


\section{BIBLIOGRAPHY}

Works Cited:

Baker, Jeff. "Plucking the American Albatross: Pynchon's Irrealism in Mason \& Dixon." Pynchon and Mason \& Dixon. Eds. Brooke Horvath and Irving Malin. London: Associated UP \& Newark: U of Delaware P, 2000. 167-188.

Berger, James. “Cultural Trauma and the 'Timeless Burst': Pynchon's Revision of Nostalgia in Vineland." Postmodern Culture 5.3 (1995): 1-19.

Brigg, Peter. The Span of Mainstream and Science Fiction: A Critical Study of a New Literary Genre. Jefferson, NC \& London: McFarland \& Company, Inc. 2002.

Cannon, Lou. Reagan. New York: G.P. Putnam, 1982.

Chambers, Judith. Thomas Pynchon. New York: Twayne Publishers, 1992.

Coale, Samuel Chase. Paradigms of Paranoia: The Culture of Conspiracy in Contemporary American Fiction. Tuscaloosa: U of Alabama P, 2005.

Dickson, David. The Utterance of America: Emersonian Newness in Dos Passos' U.S.A. and Pynchon's Vineland. Ph.D. diss., Göteborg University, 1998.

Gosse, Van, "Unpacking the Vietnam Syndrome: The Coup in Chile and the Rise of Popular AntiInterventionism." The World the Sixties Made: Politics and Culture in Recent America. Eds. Van Gosse \& Richard Moser. Philadelphia: Temple UP, 2003. 100-113.

Harris, Michael. "Pynchon's Postcoloniality." Thomas Pynchon: Reading from the Margins. Ed. Niran Abbas. Fairleigh Dickinson UP \& London: Associate UP, 2003. 199-214.

Heale, M. J. The Sixties in America: History, Politics and Protest. Edinburgh UP, 2001.

Helms, Harry. Inside the Shadow Government: National Emergencies and the Cult of Secrecy. Feral House, 2003.

Leonard, John. "Crazy Age of Reason.” Review of Mason \& Dixon, by Thomas Pynchon. The Nation. (May1997) 12: 65-68.

Madsen, Deborah L. The Postmodernist Allegories of Thomas Pynchon. Leicester, London: Leicester UP, 1991.

Mattessich, Stefan. Lines of Flight: Discursive Time and Countercultural Desire in the Work of Thomas Pynchon. Durham and London: Duke UP, 2002.

Moser, Richard. "Was It the End or Just a Beginning? American Storytelling and the History of the Sixties."The World the Sixties Made: Politics and Culture in Recent America. Eds. Van Gosse \& Richard Moser. Philadelphia: Temple UP, 2003. 37-51.

Ostrander, Madeline. "Awakening to the Physical World: Ideological Collapse and Ecofeminist Resistance in Vineland."Thomas Pynchon: Reading from the Margins. Ed. Niran Abbas. Fairleigh Dickinson UP \& London: Associate UP, 2003. 122-135.

Pynchon, Thomas. Gravity's Rainbow. 1973. Vintage, 2000.

---. Vineland. Boston, Toronto, London: Little, Brown and Company, 1990.

Rielly, Edward J. The 1960s. Westport, Connecticut \& London: Greenwood P, 2003. 
Strehle, Susan. Fiction in the Quantum Universe. Chapel Hill and London:U of North Carolina P, 1992.

Thoreen, David. "The Fourth Amendment and Other Modern Inconveniences: Undeclared War, Organized Labor, and the Abrogation of Civil Rights in Vineland." Thomas Pynchon: Reading from the Margins. Ed. Niran Abbas. Fairleigh Dickinson UP \& London: Associate UP, 2003. 215-233.

Velčić, Vlatka. Breaking the "Conspiracy of Silence": Novelistic Portrayals of the Sixties and the Left in Doctorow, Boyle, DeLillo, and Pynchon. Ph.D. diss., Los Angeles: U of California, 1995

\section{ABSTRACTS}

This paper delineates a revolutionary period in postmodern America: the sixties from the vantage point of the eighties as presented in Thomas Pynchon's Vineland. It brings controversial aspects of U.S. history and culture into view: the blacklist period in the 1950s, the rise of counterculture and the hippie movement, and the politics of the eighties. With their arrival, each new generation pushes aside the old and implements their own ideologies, which gives this space (Vineland and the U.S. in general) utopian and post-utopian characteristics at the same time. It is a crossroads which generation after generation has inhabited, with layers of history that overlap, underlying the ideological battles between woge and humans, Indians and the whites, the Left and the Right, hippies and the Nixon administration, various marginal groups (mostly reminders of the hippy generation) and the Reaganite politics.

\section{INDEX}

Keywords: eighties, history, ideology, post-utopia, sixties, utopia, Vineland

\section{AUTHORS}

\section{LOVORKA GRUIC GRMUSA}

University of Rijeka, Croatia 